\title{
Influence of Plant Densities Interacted with Boron Foliar spraying on sunflower productivity
}

\author{
Abido, W.A.E. ${ }^{1}$ and El-Shimaa A.M. Abo-El-Kheer ${ }^{2}$ \\ ${ }^{1}$ Agronomy Department, Faculty of Agriculture, Mansoura University, Egypt. \\ ${ }^{2}$ Agricultural Botany Department, Faculty of Agriculture, Mansoura University, Egypt.
}

Received: 19 Dec. 2019/ Accepted 30 Jan. 2020 / Publication date: 25 April. 2020

\begin{abstract}
Plant densities and born fertilizer had a great importance among the agronomic factors that have a strong effect on plant productivity. For this reason, two experiments were performed at Kafralgraidh Village, Kafrelshiekh Governorate, Egypt, during 2018 and 2019 summer seasons using a strip-plot design with four replicates to investigate the effects of four plant densities (23333, 28000, 35000 and $46666 \mathrm{plant} / \mathrm{fed})$ resulted from four hill spacing $(30,25,20$ and $15 \mathrm{~cm})$, respectively and five boron foliar application i.e. without foliar spraying as control treatment, foliar spraying with water and three levels of boron foliar fertilizer (100, 150 and $200 \mathrm{ppm}$ ), on growth parameters, yield, its attributes, seeds oil content and its qualities of sunflower. The obtained results declared that plant densities significantly affected plant growth characters, yield, and its attributes and oil content as well as oil qualities. Results indicated that the maximum averages of total chlorophyll content, stem height, stem diameter, head diameter, 1000-achenes weight and achenes weight/head were resulted from the lowest plant density 23333 plants/fed. While, the highest averages of leaf area index (LAI), crop growth rate (CGR), relative growth rate (RGR), achenes yield/fed and oil, oleic and linoleic contents were recorded with a plant density of 35000 plants/fed. Otherwise, increasing plant density from 23333 to $46666 \mathrm{plant} / \mathrm{fed}$ caused a gradual increased in palmitic and stearic contents. Data also declared that the foliar spraying with boron significantly influenced all studied characters. The maximum averages of all studied characters were recorded from foliar spraying with $200 \mathrm{ppm}$ of boron. Therefore, for maximizing the achenes yield oil content of sunflower plants it could be recommended to sowing at a plant density of 35000 plants/fed resulted from hill spacing $20 \mathrm{~cm}$, also spraying plants with $200 \mathrm{ppm}$ of boron under the ecological conditions of the experiment area.
\end{abstract}

Keywords: Sunflower, Helianthus annuus L., plant density, hill spacing, boron levels, foliar fertilization, growth, yield, oil content.

\section{Introduction}

Sunflower (Helianthus annuus L.) is considered one of the most important sources of vegetable oil crops, ranks after peanut and soybean according to the world total production (Ramula et al., 2011). Sunflower oilseed is useful for humans due to its high oil content about 45-55\%, protein content about $30-35 \%$, carbohydrates about $18-19 \%$, linoleic acid about $72.5 \%$, oleic acid about $16.2 \%$ and polyunsaturated fatty acids about $60 \%$ as well as the oil also is a source of many vitamins i.e. A, D, E and K (Amirian et al., 2013). According to (FAO, 2020) the total cultivated area of sunflower in Egypt reached about 6000 hectares with a total production of 20000 tons. Conversely, the total cultivated area in the world reached about 26.533 million ha with a total production of 47.863 tons. In general, there is a shortage and a big gap between oil consumption and its production in Egypt and this gap is continuously raised due to stable raise in the human population. For this reason, using suitable agricultural practices i.e. sowing the suitable plant number per unit area and foliar spraying with some micronutrients such as boron may improve sunflower growth characters, yield attributes, yield per unit area and oil content and its qualities.

Plant densities affect growth characters and yield of sunflower through planting optimum LAI to reduce the competition between plants by more light penetration on plant canopies, consequently enhances photosynthesis process, then increase photosynthesis rate which consequently increase yield per unit area. Moreover, it is usually used in matching crop requirements to the environmental resources available. Furthermore, it is critical practices for determining the most favorable above ground surroundings that allows the plant to obtain the necessary environmental growth

Corresponding Author: Abido, W.A.E., Agronomy Department, Faculty of Agriculture, Mansoura University, Egypt. E-mail: madawy78@mans.edu.eg 
factors i.e. light, space, water, $\mathrm{CO}_{2}$, and nutrients, which are significant tools to optimize the plant growth and accumulate and production of dry matter as well as consequently maximize the final seeds yield and its quality (Basha, 2000; Beg et al., 2007 and Biabani, 2010). In addition, number of plants per unit area play vital role in adjusting the crop environment and assist to improve disease avoidance, therefore modulating number of plant per unit area is the main instrument to improve plant growth and the time required for plant canopy closure and to produce the highest quantity of biomass and seed yield (Khan et al., 2003 and Liu et al., 2008). Diepenbrock et al. (2001) reported that due to the increasing of interplant competition for space, light, $\mathrm{CO}_{2}$, water, and nutrients and other life factors, the growth characters and yield and its attributes of sunflower plants are probable to decline with raising the number of plants per unit area. While, under the optimum number of plants per unit area, growth, yield, and its attributes were expected to increase. Ali et al. (2012) and Ibrahim (2012) declared that plant growth characters, yield and attributes of sunflower plants significantly influenced by plant densities. The maximum averages of leaf area, head diameter, 100-seed weight, and oil percentage were produced under the lowest plant density (45000 plants/ha). While the highest plant density (75000 plants/ha) resulted in the highest means of plant height. Süzer (2010) and Ion et al. (2015) indicated that row spacing influenced the yield attributes of sunflower. Furthermore, raising plant densities from $50,000,60,000$ to 70,000 plants per ha significantly decreased growth characters, yield attributes as well as seed yield of sunflower. They also added that the optimum number per unit area led sunflower capable to use the growing resources such as solar radiation, $\mathrm{CO}_{2}$, water, and nutrients. Increasing hill spacing from 15, 20 and $25 \mathrm{~cm}$ produced the maximum values of leaf area/plant, stem diameter, head diameter, number of seeds/head, 1000-seed weight. Also, they concluded that the tallest plants and highest seed yield were produced from 20 or $30 \mathrm{~cm}$ hill spacing (Kandil et al., 2017 and Ravichandran and Srinivasan, 2017). Killi (2004) and Ishfaq et al. (2009) declared that an increasing number of plants per unit area caused an increase in seeds oil content.

Foliar fertilization is considering an effective technique to overcoming the shortage of some essential nutrients in the soil, by applying nutrients directly to the leaves of plants. Which maybe is the most efficient way to improve the growth, plant health and increase the yield of the plant (Mosali et al., 2006). Boron (B) is considering one of essential micronutrients and play an important roles as enzymatic activator function, transport of carbohydrates, operating in ion absorption processes, synthesis of nucleic acids (DNA and RNA), lignin, cellulose and proteins (Brown et al., 2002). In addition, increase the chlorophyll content, photosynthesis rate, the synthesis of cell wall structure, flower retention, reproduction of plants, the germination of pollen, metabolisms of protein, nucleic acid, carbohydrate, indole acetic acid, phenol, sugar transport and seed setting (Farzanian et al., 2010). Also, it is improving the growth of the pollen tube and there is a good correlation among the content of B in the plant tissue and the total number of flowers, the percentage of flowers not aborted and seed setting (Wimmer and Eichert, 2013). Brighenti and Castro (2008) stated that increasing boron levels led to minimizing the percentage of the empty grain and increased the pollen fertility, achenes yield as well as oil content of sunflower plants. Tahir et al. (2014) and Saleem et al. (2016) indicated that boron application had a significant effect on all studied characters i.e. plant height, leaf area, chlorophyll content, stem diameter, head diameter, number of seeds/head, 1000seeds weight, seed yield/ha and oil content of sunflower plants. The highest mean values of these characters were recorded with increasing boron levels up to $8 \mathrm{~kg} / \mathrm{ha}$. Mekki (2015) and Shehzad et al. (2016) showed that increasing boron levels from 300 to $600 \mathrm{ppm} /$ ha caused significant influence on growth (plant height, stem diameter, and LA) and yield components (number of seeds/head, head diameter, seeds yield/plant, 1000-seed weight, oil content). Furthermore, seeds yield increased by $30.83 \%$ due to the increased of boron level from 300 to $600 \mathrm{ppm}$ as compared with no foliar spraying with boron.

Nowadays, there is no accurate and comprehensive information regarding the effect of plant densities and boron fertilizer levels as a foliar application on the growth characters, yield and its attributes as well as seed oil content of sunflower plant. Therefore, this investigates proposed to study the effects of plant densities and boron fertilizer levels as a foliar application on the growth, yield and its attributes as well as seed oil content and its qualities of sunflower plants under the same environmental conditions of experimental area. 


\section{Material and Methods}

\section{Study site and objective:}

Under the environmental conditions of Kafralgraidh Village, Kafrelshiekh Governorate, Egypt, two summer field experiments were performed during 2018 and 2019 seasons to study the effects of plant densities and boron levels as foliar fertilization on the growth characters, yield and its attributes as well as seed oil content and its qualities of sunflower cultivar Sakha 53. The sunflower cultivar under study (Sakha 53) was obtained from Oil Research Section, Field Crops Research Institute, Agricultural Research Center, Giza, Egypt.

\section{Experimental design and treatments:}

Two factors were studied in a strip-plot design with four replicates. Each experiment included twenty treatments comprising, four plant densities and five foliar spraying treatments. The verticalplots were included four plant densities $(23333,28000,35000$ and 46666 plant/fed). Sunflower achenes were regular hand planting at the denoted hill spacing $(30,25,20$ and $15 \mathrm{~cm}$ on one side 60 $\mathrm{cm}$ ridge) to produce the tested plant densities and then after 21 days from sowing it thinned to one plant/hill. While, the horizontal-plots were devoted to five foliar spraying treatments with boron i.e. without (control treatment), spraying with water, spraying with boron at 100, 150 and 200 $\mathrm{ppm}$. Boron fertilizer in the form of boric acid $\left(\mathrm{H}_{3} \mathrm{BO}_{3} 17 \% \mathrm{~B}\right)$ was used. The foliar solution volume was 200 Liter water/fed. The foliar application was done after 40 day from sowing (DFS) by using hand sprayer until saturation point.

Experimental plots consisted of five ridges, each $3.5 \mathrm{~m}$ in length and $0.6 \mathrm{~m}$ width and the total of the experimental unit area was $10.5 \mathrm{~m}^{2}$ (one feddan $=4200 \mathrm{~m}^{2}$ ). Soil samples were taken randomly before crop sowing in each season at a depth of 0-30 cm to determine the physical and chemical analysis of the soil. The soil of the experimental field was clayey loam, $\mathrm{pH} 7.85$, EC $1.45 \mathrm{dS} / \mathrm{m}$, organic matter $0.95 \%$, available contents of $\mathrm{N}, \mathrm{P}, \mathrm{K}$, and B were $0.075 \mathrm{ppm}, 19.7 \mathrm{ppm}, 245 \mathrm{ppm}$, and $0.51 \mathrm{ppm}$, respectively as average of both seasons. The preceding crop in both seasons was Egyptian clover.

The experimental field was well prepared and phosphorous fertilizer as a form of calcium superphosphate $\left(15.5 \% \mathrm{P}_{2} \mathrm{O}_{5}\right)$ was applied at the rate of $100 \mathrm{~kg} / \mathrm{fed}$ during the preparation of the soil. Sunflower seeds at the rate of $5 \mathrm{~kg} /$ fed sown on the 20th of May in the first and second seasons. Nitrogen fertilizer was applied at the rate of $90 \mathrm{~kg} / \mathrm{fed}$ in the form of ammonium nitrate $(33.5 \% \mathrm{~N})$ in two portions before the first and the second irrigations. Furthermore, potassium fertilizer was applied at the rate of $50 \mathrm{~kg} / \mathrm{fed}$ in the form of potassium sulfate $\left(48 \% \mathrm{~K}_{2} \mathrm{O}\right)$ in one portion with the second portion of nitrogen. All other recommended agricultural practices for growing sunflower were followed as described by the recommendations of the Ministry of Agriculture, except the factors under study.

\section{Studied characters:}

After 60 day from sowing (DFS), five randomly guarded plants from the outer ridges of each plot were taken to estimate the following growth characters:

1-Total chlorophyll (SPAD): It was estimated by using the SPAD-502 (Minolta Co. Ltd., Osaka, Japan).

2-Leaf area index (LAI): It was calculated by estimate leaf area $\left(\mathrm{cm}^{2}\right)$ according the following equation as described by (Schneiter 1978):

$$
\mathrm{LA}=(\mathrm{L} \times \mathrm{B} \times 0.6683)-2.45 \mathrm{~cm}^{2}
$$

where, $\mathrm{L}=$ Leaf length and $\mathrm{B}=$ Leaf breadth.

After that LAI was calculated by dividing leaf area $\left(\mathrm{cm}^{2}\right)$ on the land area of one plant $\left(\mathrm{cm}^{2}\right.$ in each density studied).

3-Crop growth rate (CGR) in g/day was determined according to Radford (1967), using the following equation:

$$
\mathrm{CGR}=\frac{\mathrm{W}_{2}-\mathrm{W}_{1}}{\mathrm{~T}_{2}-\mathrm{T}_{1}}
$$

Where: $\mathrm{W}_{1}$ and $\mathrm{W}_{2}$ mention to the dry weight of plant at sampling recorded after 60 and $75 \mathrm{DFS}\left(\mathrm{T}_{1}\right)$ and time $\left(\mathrm{T}_{2}\right)$, respectively. 
4-Relative growth rate (RGR) in g/day: It was estimated regarding to Radford (1967), using the following equation:

$$
\mathrm{RGR}=\frac{\log _{\mathrm{e}} \mathrm{W}_{2}-\log _{\mathrm{e}} \mathrm{W}_{1}}{\mathrm{~T}_{2}-\mathrm{T}_{1}}
$$

Where: Loge: refer to the natural $\log$ and $\mathrm{W}_{1}$ and $\mathrm{W}_{2}$ refers to the dry weights of plant at sampling recorded after 60 and $75 \mathrm{DFS}\left(\mathrm{T}_{1}\right)$ and time $\left(\mathrm{T}_{2}\right)$, respectively.

After harvesting (105 DFS), five randomly guarded plants from the inner ridges of each plot were taken and air dried for about one week, then the subsequent characters were assessed: stem height $(\mathrm{cm})$; stem diameter $(\mathrm{cm})$, head diameter $(\mathrm{cm})$, number of achenes/head, 1000-achenes weight $(\mathrm{g})$, achenes weight/head $(\mathrm{g})$ and achenes weight ton/fed, which was determined from harvest all plants of the three inner ridges and the achenes weight was calculated on base of $12-13 \%$ moisture content then weighted and converted to tons/fed. Oil content and its qualities (oleic, linoleic, palmitic and stearic contents) were determined according to AOAC (2016).

\section{Statistical analysis:}

Data were statistically analyzed using MSTAT statistical package using a strip-plots design with four replicates as described by Gomez and Gomez (1984). Furthermore, treatment means were compared by using Least Significant Difference (LSD) at $5 \%$ level of probability as mentioned by Snedcor and Cochran (1980).

\section{Results and Discussion}

\section{A-Plant densities effect:}

The results indicated that plant densities showed a significant effect on total chlorophyll content (SPAD), leaf area index (LAI), crop growth rate (CGR), relative growth rate (RGR), stem height $(\mathrm{cm})$, stem diameter $(\mathrm{cm})$, head diameter $(\mathrm{cm})$, number of achenes/head, 1000-achenes weight $(\mathrm{g})$, achenes weight/head (g), achenes weight ton/fed and oil qualities during two growing seasons as presented in Tables 1,2 and 3. It can be noticed that the lowest plant density (23333 plants/fed) produced the maximum values of the following characters; (total chlorophyll, stem diameter, head diameter, number of achenes/head, 1000-achene weight and achenes weight/head) in both seasons. These results may be attributed to the fact that individual plants at low plant densities adjust to low populations by increasing the vegetative growth in wide plant spacing and low plant density and this support producing the maximum values of above-mentioned characters (Kandil et al., 2017 and Ravichandran and Srinivasan, 2017. Whereas, the minimum values of total chlorophyll, stem diameter, head diameter, number of achenes/head, 1000-achene weight, achenes, and weight head resulted from the highest plant density (46666 plant/fed) in both seasons (Diepenbrock et al., 2001; Süzer, 2010 and Ion et al., 2015). Regarding the values of LAI, CGR, and RGR, the obtained results declared that increasing plant densities from 23333, 28000 to 35000 plant/fed caused a gradual increase in LAI, CGR, and RGR in both seasons. The highest LAI, CGR, and RGR value resulted in plant density 35000 plant/fed may be due to higher leaf area per plant which reflected on the higher value of LAI. Also, wider hill spacing might have increased the root spread which eventually utilized the applied nutrients and water, which reflected on the higher leaf area. Also, this might be attributed to the minimal competition among the plants under fewer plant density 23333 plants/fed. The data also showed that the highest plant densities (46666 plants/fed) produced the tallest plants as compared with the lowest plant density ( 23333 plants/fed) during the two growing seasons. The increases in stem height due to the increase of plant density may be attributed to more competition between plants for space, nutrients, light, consequently lead to more plant elongation. These results are in a good line with the findings of (Ali et al., 2012 and Ibrahim, 2012). The highest value of achenes yield/fed was obtained with planting sunflower at the plant density ( 35000 plants/fed), followed by the plant density ( 28000 plants/fed) in both seasons. On the other hand, the lowest values of achenes yield/fed were recorded with plant densities (46666 and 23333 plant/fed) in both seasons. It can be concluded that plant density of 35000 plants/fed caused an increase in achenes yield/fed reached about 56.64, 22.91 and $36.20 \%$ as compared with plant density 23333,28000 and 46666 plant/fed, respectively as an average over both growing seasons. The increases in achenes yield per unit area of sunflower could be obtained at plant density ( 35000 plants/fed) may be attributed to the adequate of environmental 
conditions in wide spacing and the minimal competition between sunflower plants as well as increase light penetration within plant canopy which might have provided sufficient space to the crop to harness the solar energy and utilization of applied nutrients and moisture effectively, which reflected on leaf area and dry matter production per plant and a stimulation of the conversion of photosynthate to seed instead of vegetative growth would be agronomically useful, consequently and achenes yield per unit area (Khan et al., 2003; Liu et al., 2008; Ali et al., 2012 and Ibrahim, 2012).

Concerning, oil and its qualities, the data presented in Table 3 stated that oil, oleic acid, and linoleic acid percentages were gradually increased with increasing plant density from 23333 to 35000 plant/fen, then decreased with the highest plant densities 46666 plant/fed in both seasons. On the contrary, the highest values of palmitic and stearic acid percentages were increased with increasing plant density up to 46666 plants/fed during both seasons. These results may be due to When planting the optimum number of plants per unit area, the rate of vegetative growth characters increase and the net results of the photosynthesis process increase and the dry matter that moves to the seeds increases and consequently, oil content increase. These obtained results are in accordance with Ali et al., 2012 and Ibrahim, 2012. On the contrary, Killi (2004) and Ishfaq et al. (2009) found that the oil percentage was decreased with increasing plant density.

\section{B-Foliar spraying treatments with boron effect:}

Foliar spraying treatments with boron (without, spraying with water and foliar spraying with boron at 100,150 and $200 \mathrm{ppm}$ ) had a significant effect on the growth characters, yield, and its attributes as well and oil content and its qualities in both seasons as presented in Tables 1, 2 and 3. The data clearly showed that spraying sunflower plants with the highest values of boron (200 ppm) surpassed other foliar spraying treatments and recorded the maximum values of all growth characters, yield, and yield attributes as well as oil qualities through both seasons. It is noticed that foliar spraying with boron at $200 \mathrm{ppm}$ increased total chlorophyll by $(7.87,7.58,4.65$ and $2.52 \%)$, LAI by (30.66, $26.73,12.05$ and $4.43 \%)$, CGR by $(18.75,15.73,10.14$ and $4.10 \%)$, RGR by $(16.19,13.71,7.60$ and $3.21 \%$ ), stem height by $(7.70,6.92,3.56$ and $1.19 \%)$, stem diameter by $(53.89,33.97,14.86$ and $7.35 \%)$, head diameter by $(15.88,14.15,6.53$ and $2.72 \%)$, number of achenes/head by $(11.71,9.50$, 3.12 and $1.40 \%), 1000$-achene weight by $(10.06,10.51,5.95$ and $2.72 \%$ ), achenes weight/head by $(22.25,20.40,12.13$ and $2.67 \%)$, achenes yield ton/fed by $(26.96,23.92,16.77$ and $9.59 \%)$, oil contents by $(5.86,4.94,2.68$ and $1.36 \%)$, oleic acid contents by $(7.55,6.72,4.15$ and $1.78 \%)$, linoleic acid contents by $(2.56,2.59,1.86$ and $0.88 \%)$, palmitic acid contents by $(16.45,10.71,6.99$ and $3.02 \%)$ and stearic acid contents by $(18.32,12.90,8.24$ and $3.34 \%)$ as compared with other foliar spraying treatments (without, spraying with water, spraying with boron at $100 \mathrm{ppm}$ and spraying with boron at $150 \mathrm{ppm}$ ) as an average over both growing summer seasons, respectively. These results are in confirmation with the discovery of Brighenti and Castro (2008); Tahir et al. (2014); Saleem et al. (2016); Mekki (2015) and Shehzad et al. (2016). The increases in growth characters, yield and yield attributes of sunflower plants with foliar spraying with high level of boron (200 ppm) might be due to the vital role of boron as important micronutrient which increase the total chlorophyll content, LAI, photosynthesis rate, the synthesis of cell wall structure, metabolisms of protein, nucleic acid, carbohydrate, indole acetic acid, phenol, sugar transport and seed setting, germination of pollen, improving the growth of pollen tube, increase pollen fertility, minimize the empty achenes percentage, consequently, increase achenes yield and oil content. These results coincide with those found by Mosali et al. (2006); Brighenti and Castro (2008); Farzanian et al. (2010) and Wimmer and Eichert (2013).

\section{C-Interaction effect:}

As revealed from the data graphically illustrated, the favorable interaction treatment which recorded the highest values of LAI (Fig. 1), CGR (Fig. 2), RGR (Fig. 3), stem height (Fig. 4), stem diameter (Fig. 5), number of achenes/head (Fig. 6), 1000-achenes weight (Fig. 7), achenes weight/head (Fig. 8) and achenes yield ton/fed (Fig. 9) were resulted from planting sunflower at 35000 plants/fed beside spraying with boron at $200 \mathrm{ppm}$ in both seasons. While the highest percentages of oil (Fig. 10) were recorded with the lowest plant density (23333 plants/fed) beside foliar spraying with $200 \mathrm{ppm}$ boron. The increases in achenes yield per unit area at 35000 plants/fed beside foliar spraying with boron at $200 \mathrm{ppm}$ might be due to the adequate of environmental 
conditions at 35000 plant/fed and the minimal competition between sunflower plants as well as increase light penetration within plant canopy which might have provided sufficient space to the crop to harness the solar energy and utilization of applied nutrients and moisture effectively. Moreover, the important role of boron in increasing plant growth character. Consequently, increase dry matter production per plant and a stimulation of the conversion of photosynthate to seed instead of vegetative growth would be agronomically useful, consequently increase achenes yield per unit area (Brighenti and Castro (2008); Liu et al., 2008; Ibrahim, 2012; Farzanian et al. (2010); Tahir et al. (2014) and Saleem et al. (2016).

Table 1: Averages of total chlorophyll (SPAD), leaf area index (LAI), crop growth rate (CGR), relative growth rate $(\mathrm{RGR})$, stem height $(\mathrm{cm})$ and stem diameter $(\mathrm{cm})$ as influenced by plant densities, foliar spraying treatments with boron, and their interaction during 2018 and 2019 summer seasons.

\begin{tabular}{|c|c|c|c|c|c|c|c|c|c|c|c|c|}
\hline \multirow{2}{*}{$\begin{array}{c}\text { Characters } \\
\text { Treatments } \\
\text { Seasons }\end{array}$} & \multicolumn{2}{|c|}{$\begin{array}{c}\text { Total } \\
\text { chlorophyll } \\
\text { (SPAD) } \\
\end{array}$} & \multicolumn{2}{|c|}{ LAI } & \multicolumn{2}{|c|}{$\begin{array}{l}\text { CGR } \\
\text { g/day }\end{array}$} & \multicolumn{2}{|c|}{$\begin{array}{l}\text { RGR } \\
\text { g/day }\end{array}$} & \multicolumn{2}{|c|}{$\begin{array}{l}\text { Stem height } \\
\text { (cm) }\end{array}$} & \multicolumn{2}{|c|}{$\begin{array}{l}\text { Stem diameter } \\
(\mathrm{cm})\end{array}$} \\
\hline & 2018 & 2019 & 2018 & 2019 & 2018 & 2019 & 2018 & 2019 & 2018 & 2019 & 2018 & 2019 \\
\hline 23333 plant/fed & 5.08 & 5.26 & 3.70 & 3.81 & 1.47 & 1.54 & 1.90 & 1.95 & 164.36 & 166.65 & 2.72 & 3.13 \\
\hline 28000 plant/fed & 3.90 & 3.99 & 4.42 & 4.38 & 2.47 & 2.49 & 2.06 & 2.09 & 169.98 & 172.48 & 2.31 & 2.98 \\
\hline 35000 plant/fed & 3.32 & 3.48 & 5.00 & 5.17 & 2.64 & 2.67 & 2.93 & 2.99 & 177.62 & 179.54 & 1.74 & 2.67 \\
\hline \multicolumn{13}{|c|}{ B- Foliar spraying treatments with boron effects: } \\
\hline Without (control) & 3.68 & 3.80 & 3.66 & 3.75 & 1.90 & 1.94 & 2.04 & 2.10 & 167.73 & 171.08 & 1.65 & 2.07 \\
\hline Water & 3.69 & 3.81 & 3.77 & 3.87 & 1.95 & 1.99 & 2.09 & 2.14 & 169.34 & 171.91 & 1.81 & 2.49 \\
\hline $100 \mathrm{ppm}$ boron/fed & 3.79 & 3.92 & 4.27 & 4.37 & 2.05 & 2.09 & 2.22 & 2.25 & 175.15 & 177.19 & 2.15 & 2.85 \\
\hline $150 \mathrm{ppm}$ boron/fed & 3.88 & 3.99 & 4.59 & 4.68 & 2.17 & 2.21 & 2.31 & 2.35 & 179.30 & 181.29 & 2.30 & 3.05 \\
\hline $200 \mathrm{ppm}$ boron/fed & 3.94 & 4.13 & 4.86 & 4.82 & 2.26 & 2.30 & 2.38 & 2.43 & 181.19 & 183.70 & 2.48 & 3.26 \\
\hline
\end{tabular}

*; significant at 0.05 level of probability and NS; non-significant at 0.05 level of probability.

Table 2: Averages of head diameter (cm), number of achenes/head, 1000-achene weight ( $\mathrm{g}$ ), achenes weight/head ( $\mathrm{g}$ ), achenes yield ton/fed as influenced by plant densities, foliar spraying treatments with boron, and their interaction during 2018 and 2019 summer seasons.

\begin{tabular}{|c|c|c|c|c|c|c|c|c|c|c|}
\hline \multirow{2}{*}{ 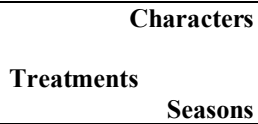 } & \multicolumn{2}{|c|}{$\begin{array}{l}\text { Head diameter } \\
(\mathrm{cm})\end{array}$} & \multicolumn{2}{|c|}{$\begin{array}{c}\begin{array}{c}\text { Number of } \\
\text { achenes/head }\end{array} \\
\end{array}$} & \multicolumn{2}{|c|}{$\begin{array}{c}\text { 1000-achene } \\
\text { weight (g) }\end{array}$} & \multicolumn{2}{|c|}{$\begin{array}{c}\text { Achenes } \\
\text { weight/head (g) }\end{array}$} & \multicolumn{2}{|c|}{$\begin{array}{c}\text { Achenes yield } \\
\text { ton/fed }\end{array}$} \\
\hline & 2018 & 2019 & 2018 & 2019 & 2018 & 2019 & 2018 & 2019 & 2018 & 2019 \\
\hline 23333 plant/fed & 20.68 & 20.94 & 943.60 & 954.00 & 63.64 & 70.14 & 57.88 & 58.84 & 807.65 & 823.22 \\
\hline 28000 plant/fed & 20.14 & 20.82 & 834.80 & 937.06 & 59.27 & 62.76 & 50.22 & 50.01 & 1102.80 & 1122.53 \\
\hline 35000 plant/fed & 19.29 & 20.48 & 851.66 & 857.40 & 57.82 & 61.03 & 48.85 & 48.34 & 1390.19 & 1399.13 \\
\hline 46666 plant/fed & 18.08 & 19.34 & 775.86 & 793.53 & 45.32 & 47.16 & 35.47 & 35.90 & 974.97 & 981.91 \\
\hline \multicolumn{11}{|c|}{ B- Foliar spraying treatments with boron effects: } \\
\hline Without (control) & 18.22 & 18.83 & 802.33 & 829.33 & 53.50 & 57.02 & 43.25 & 44.07 & 962.62 & 978.39 \\
\hline Water & 18.57 & 19.04 & 818.58 & 846.00 & 54.16 & 57.92 & 43.82 & 44.85 & 987.04 & 1001.55 \\
\hline $100 \mathrm{ppm}$ boron/fed & 19.59 & 20.72 & 865.08 & 902.66 & 56.35 & 60.57 & 47.61 & 47.58 & 1053.66 & 1056.71 \\
\hline $150 \mathrm{ppm}$ boron/fed & 20.42 & 21.38 & 878.33 & 919.58 & 58.33 & 62.24 & 52.27 & 51.69 & 1116.24 & 1132.40 \\
\hline $200 \mathrm{ppm}$ boron/fed & 20.94 & 22.00 & 893.08 & 929.91 & 60.22 & 63.62 & 53.58 & 53.16 & 1224.93 & 1239.43 \\
\hline
\end{tabular}

*; significant at 0.05 level of probability and NS; non-significant at 0.05 level of probability. 
Table 3: Averages of oil, oleic, linoleic, palmitic and stearic contents (\%) as influenced by plant densities, foliar spraying treatments with boron, and their interaction during 2018 and 2019 summer seasons.

\begin{tabular}{|c|c|c|c|c|c|c|c|c|c|c|}
\hline \multirow{3}{*}{ Treatments } & \multirow{2}{*}{\multicolumn{2}{|c|}{ Oil (\%) }} & \multirow{2}{*}{\multicolumn{2}{|c|}{ Oleic (\%) }} & \multirow{2}{*}{\multicolumn{2}{|c|}{ Linoleic (\%) }} & \multirow{2}{*}{\multicolumn{2}{|c|}{ Palmitic (\%) }} & \multirow{2}{*}{\multicolumn{2}{|c|}{ Stearic (\%) }} \\
\hline & & & & & & & & & & \\
\hline & 2018 & 2019 & 2018 & 2019 & 2018 & 2019 & 2018 & 2019 & 2018 & 2019 \\
\hline $23333 \mathrm{plant} / \mathrm{fed}$ & 40.98 & 41.42 & 25.49 & 25.82 & 65.41 & 65.68 & 6.02 & 6.66 & 4.24 & 4.34 \\
\hline 28000 plant/fed & 41.43 & 41.70 & 26.66 & 27.16 & 64.83 & 65.43 & 6.62 & 7.35 & 4.94 & 5.06 \\
\hline 35000 plant/fed & 46.31 & 46.72 & 23.52 & 24.60 & 63.44 & 64.11 & 7.64 & 8.48 & 6.26 & 6.40 \\
\hline \multicolumn{11}{|c|}{ B- Foliar spraying treatments with boron effects: } \\
\hline Without (control) & 39.07 & 39.50 & 23.00 & 24.09 & 61.94 & 63.25 & 6.62 & 7.16 & 5.14 & 5.28 \\
\hline Water & 39.36 & 39.90 & 23.24 & 24.35 & 62.25 & 62.90 & 6.90 & 7.60 & 5.40 & 5.52 \\
\hline $100 \mathrm{ppm}$ boron/fed & 40.17 & 40.84 & 23.74 & 24.89 & 62.75 & 63.29 & 7.17 & 7.83 & 5.64 & 5.75 \\
\hline $150 \mathrm{ppm}$ boron/fed & 40.76 & 41.30 & 24.31 & 25.45 & 63.50 & 63.76 & 7.43 & 8.15 & 5.88 & 6.05 \\
\hline $200 \mathrm{ppm}$ boron/fed & 41.39 & 41.79 & 24.90 & 25.74 & 64.10 & 64.29 & 7.67 & 8.38 & 6.05 & 6.28 \\
\hline
\end{tabular}

*; significant at 0.05 level of probability and NS; non-significant at 0.05 level of probability.

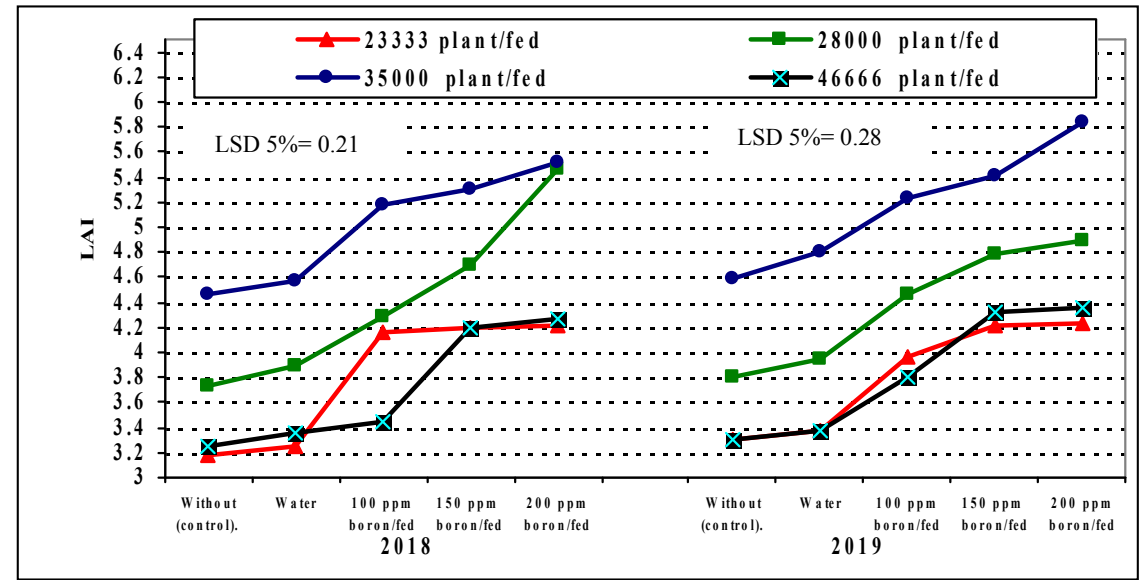

Fig. 1: Leaf area index (LAI) as influenced by the interaction between plant densities, foliar spraying treatments with boron during 2018 and 2019 summer seasons.

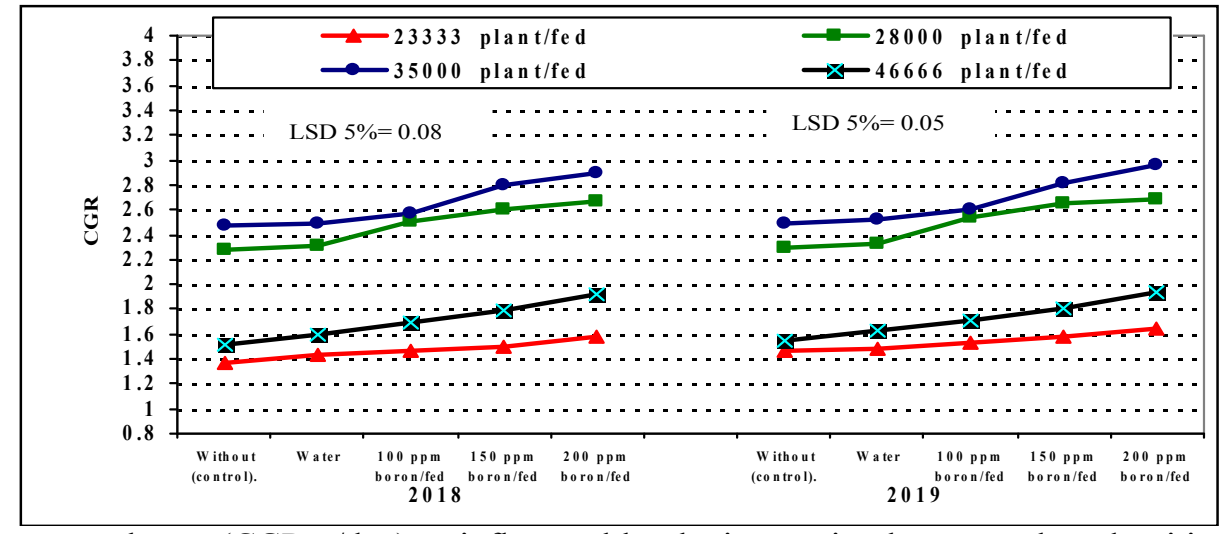

Fig. 2: Crop growth rate (CGR g/day) as influenced by the interaction between plant densities, foliar spraying treatments with boron during 2018 and 2019 summer seasons. 


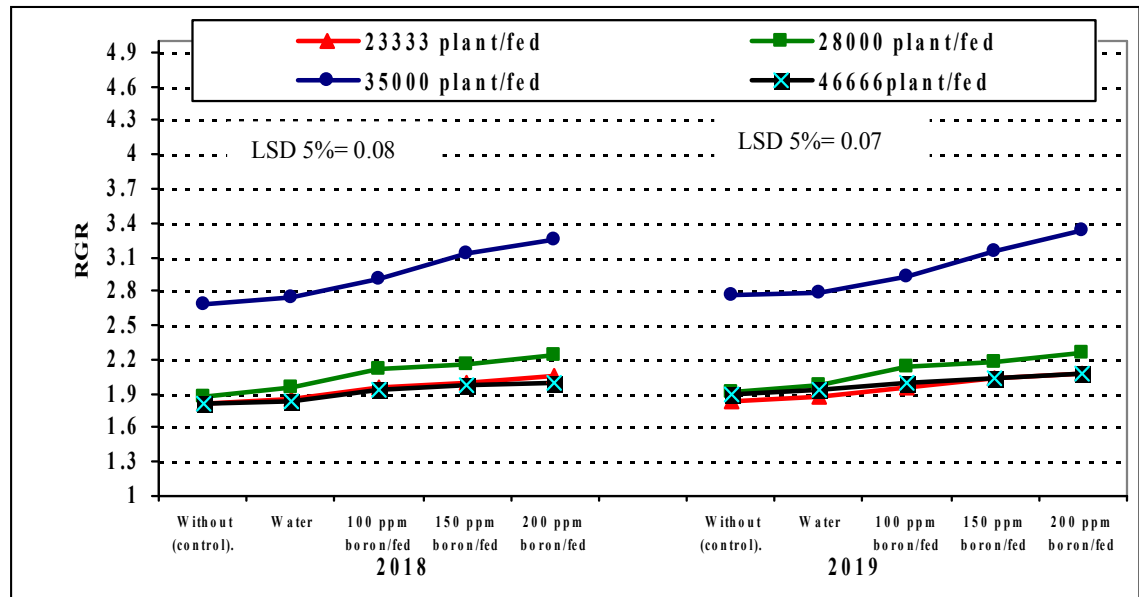

Fig. 3: Relative growth rate (RGR g/day) as influenced by the interaction between plant densities, foliar spraying treatments with boron during 2018 and 2019 summer seasons.

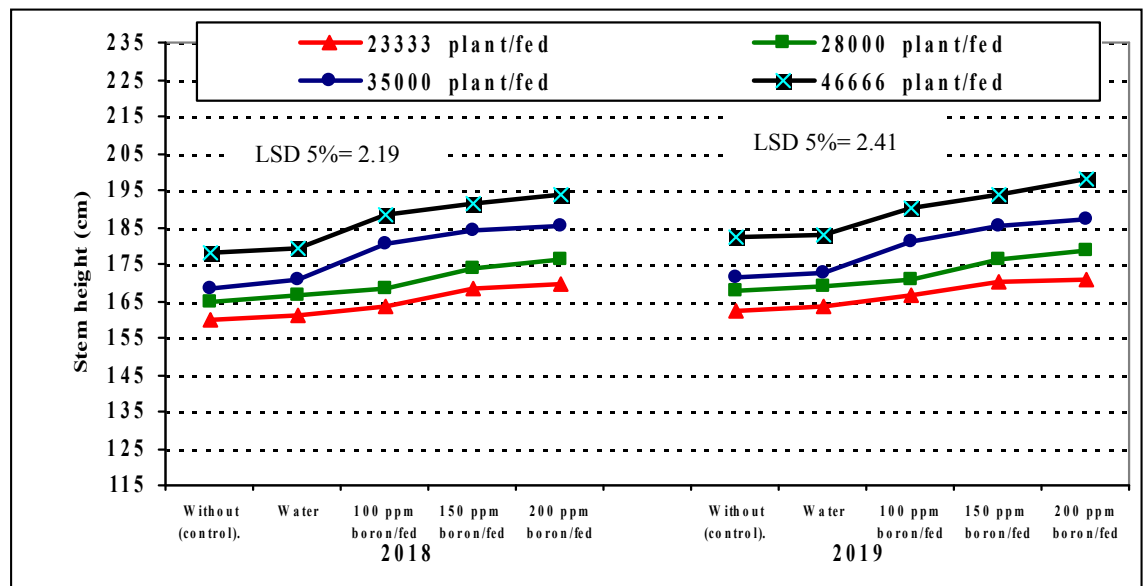

Fig. 4: Stem height $(\mathrm{cm})$ as influenced by the interaction between plant densities, foliar spraying treatments with boron during 2018 and 2019 summer seasons.

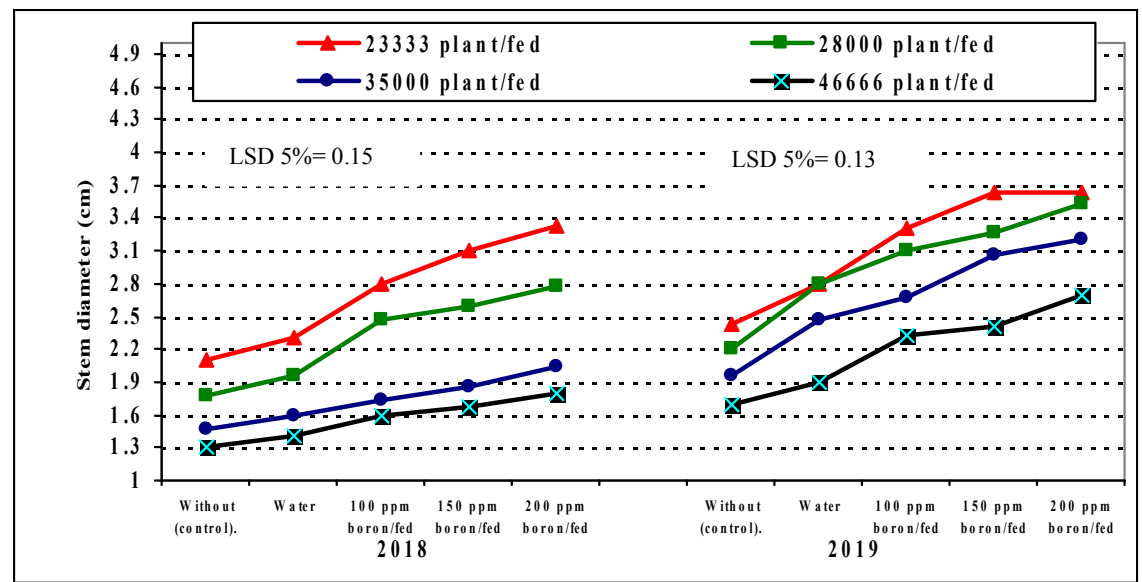

Fig. 5: Stem diameter (cm) as influenced by the interaction between plant densities, foliar spraying treatments with boron during 2018 and 2019 summer seasons. 


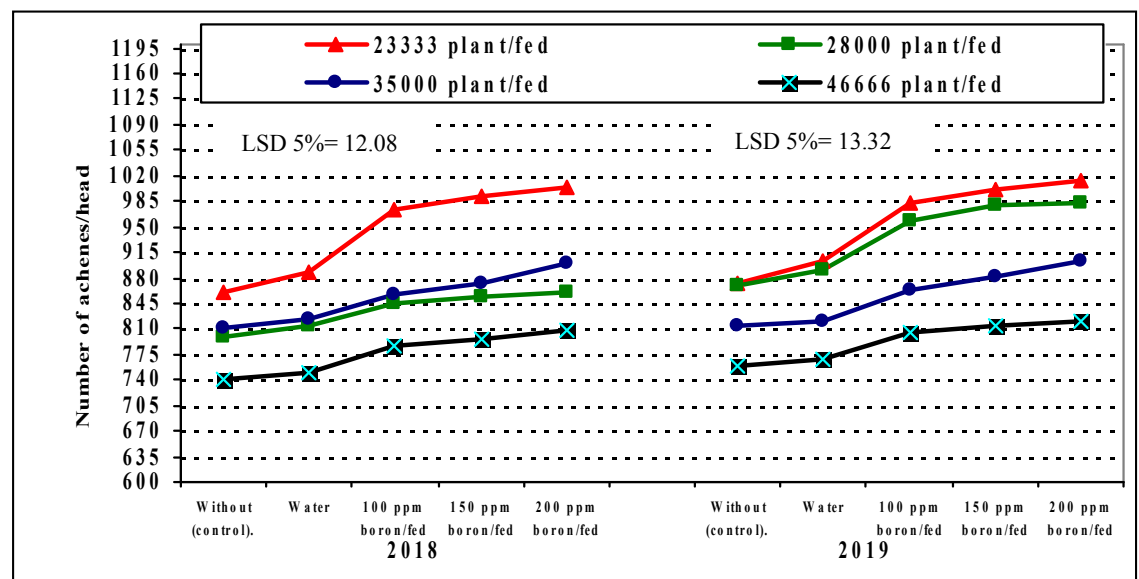

Fig. 6: Number of achenes/head as influenced by the interaction between plant densities, foliar spraying treatments with boron during 2018 and 2019 summer seasons.

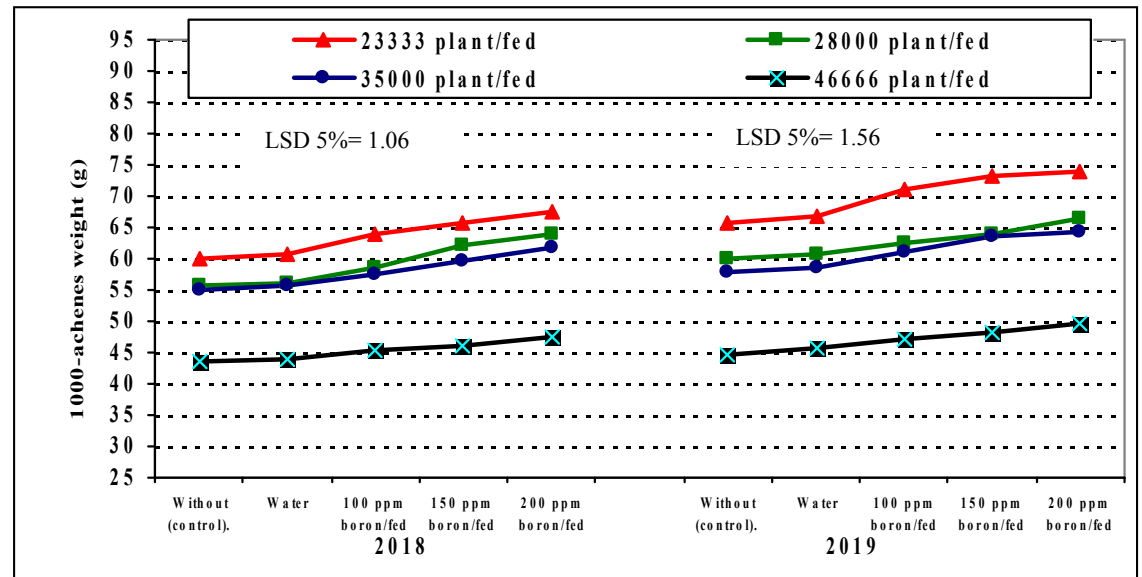

Fig. 7: 1000-achenes weight (g) as influenced by the interaction between plant densities, foliar spraying treatments with boron during 2018 and 2019 summer seasons.

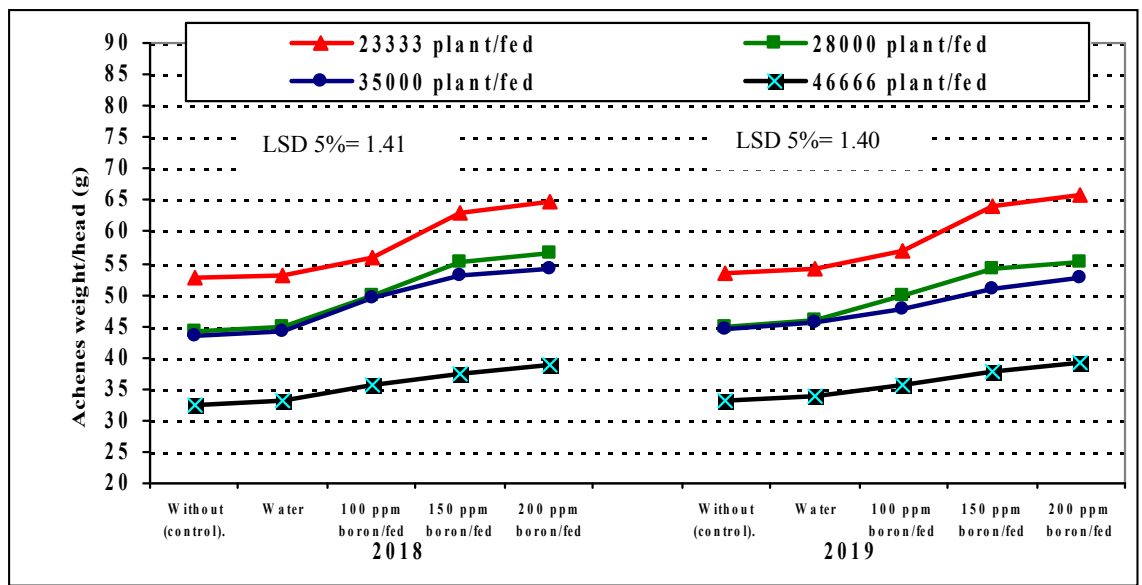

Fig. 8: Achenes weight/head (g) as influenced by the interaction between plant densities, foliar spraying treatments with boron during 2018 and 2019 summer seasons. 


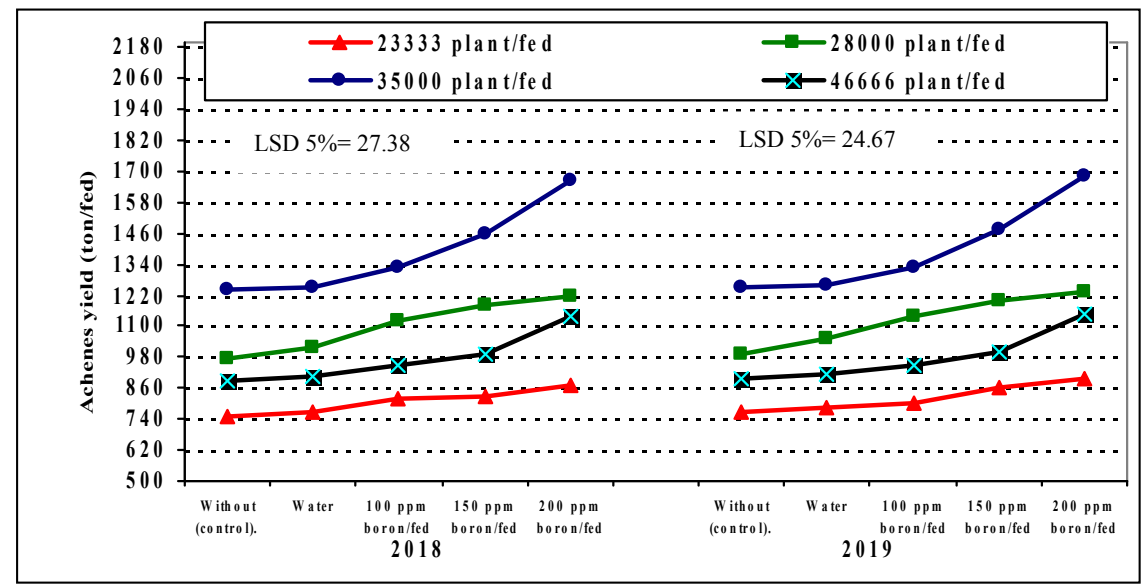

Fig. 9: Achenes yield (ton/fed) as influenced by the interaction between plant densities, foliar spraying treatments with boron during 2018 and 2019 summer seasons.

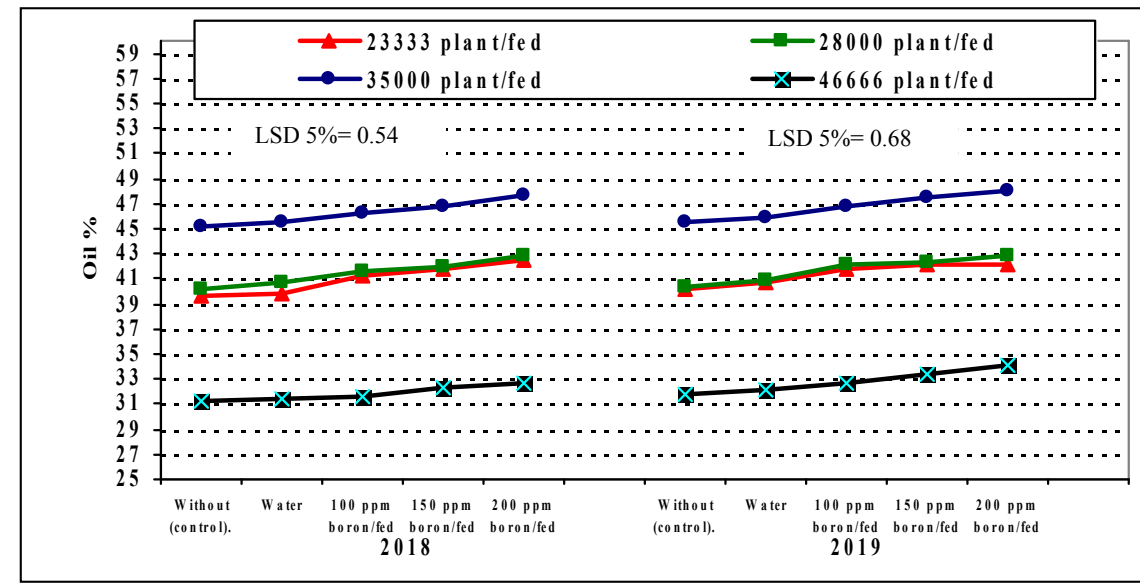

Fig. 10: Oil \% as influenced by the interaction between plant densities, foliar spraying treatments with boron during 2018 and 2019 summer seasons.

\section{Conclusion}

Based on current study findings it is recommended that for obtaining higher LAI, CGR, RGR and achene yield fed $^{-1}$ as well as oil content, sunflower cultivar Sakha 53 plants should be sown at

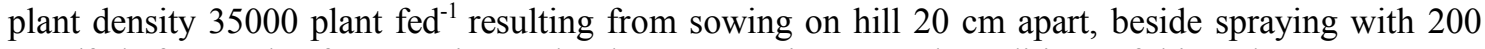
$\mathrm{ppm} /$ fed after 40 day from sowing under the same environmental conditions of this sudy.

\section{References}

Ali, A., A. Ahmad, T. Khaliq and J. Akhtar, 2012. Planting density and nitrogen rates optimization for growth and yield of sunflower (Helianthus annuus L.) hybrids. J. Anim. Plant Sci., 22(4):1070-1075.

Amirian, S., A.R. Golparvar and B. Majd-Nassiri, 2013. Character association, regression and path analysis in sunflower (Helianthus annuus L.) hybrids. TJEAS, 3(24): 3640-3643.

AOAC. 2016. Official methods of analysis. 16 ${ }^{\text {th }}$ Ed. Association of Official Analytical Chemists, Washington DC, USA.

Basha, H.A. 2000. Response of two sunflower cultivars to hill spacing and nitrogen fertilizer levels under sandy soil conditions. Zagazig Agric. Res., 27:617-633.

Beg, A., S.S. Pourdad, and S. Alipour, 2007. Row and plant spacing effects on agronomic performance of sunflower in warm and semi-cold areas of Iran. Helia, 30(47):99-104. 
Biabani, A. 2010. Cultivar and density effects on yield of soybean in double cropping. African. J. Agric. Res., 5(23): 3203-3206.

Brighenti, A.M., and C. Castro, 2008. Boron foliar application on sunflower (Helianthus annuus L.) associated with herbicides. Helia, 31(48):127-36.

Brown, P.H., N. Bellaloui, M.A. Wimmer, E.S. Bassil, J. Ruiz, H. Hu, H. Pfeffer, F. Dannel, and V. Romheld, 2002. Boron in plant biology. Plant Biol., 4:205-223.

Diepenbrock, W., M. Lang, and B. Feil , 2001. Yield and quality of sunflower as affected by row orientation, row spacing and plant density. Die Bodenkultur, 52(1): 29-36.

FAO. 2020. Food and Agriculture Organization of the United Nations, FAOSTAT, FAO Statistics Division 2020, February 2020.

Farzanian, M., M. Yarnia, A. Javanshir, and A.R. Tarinejhad, 2010. Effects of microelement application methods on seed yield components in alestar sunflower hybrid. JFAE. 8(3-4):3058.

Gomez, K.N., and A.A. Gomez, 1984. Statistical procedures for agricultural research. John Wiley and Sons, New York, $2^{\text {nd }}$ Ed., 68 P.

Ibrahim, H.M. 2012. Response of some sunflower hybrids to different levels of plant density. APCBEE Procedia, 4:175-182.

Ion, V., G. Dicu, A. Basa, M. Dumbrava, G. Temocico, L.I. Epure, and D. State, 2015. Sunflower yield and yield components under different sowing conditions. Agric. Sci. Procedia., 6:44-51.

Ishfaq, M., A. Ali, A. Khaliq, and M. Yaseen, 2009. Algometry, agronomic traits and yield of autumn planted sunflower hybrids under varying row spacing. Pakistan. J. Agric. Sci.,46(4):248-257.

Kandil, A.A., A.E. Sharief, and A.M.A. Odam, 2017. Response of some sunflower hybrids (Helianthus annuus L.) to different nitrogen fertilizer rates and plant densities. IJEAB., 2(6):2978-2994.

Khan, A.Z., P. Shah, S.K. Khalil, and F.H. Taj 2003. Influence of planting date and planting density on morphological traits of determinate and indeterminate soybean cultivars under temperature environment. Pakistan J. Agron., 2(3):146-152.

Killi, F. 2004. Influence of Different Nitrogen Levels on Productivity of Oilseed and Confection Sunflowers (Helianthus annuиs L.) under varying plant populations. Int. J. Agric. Biol., 6(4):594-598.

Liu, X., J. Jin, G. Wang, and S.J. Herbert, 2008. Soybean yield physiology and development of highyielding practices in Northeast China. Field Crops Res., 105:157-171.

Mekki, B., 2015. Effect of boron foliar application on yield and quality of some sunflower (Helianthus annuus L.) cultivars. JAST. 309-316.

Mosali, J., K. Desta, and R.K. Teal, 2006. Effect of foliar application of phosphorus on winter wheat grain yield, phosphorus uptake, and use efficiency. J. Plant Nutr., 29(12):2147-2163.

Radford, P.J., 1967. Growth analysis formulae, their use and abuse. Crop Sci., 7:171-175.

Ramula, N.K., H.M. Murthy, M.M. Jayadeva, H.S. Venkatesha, and R. Kumar, 2011. Seed yield and nutrient uptake of sunflower (Helianthus annuus L.) as influenced by different levels of nutrients under irrigated condition of eastern dry zone of Karnataka, India. Plant Arch., 11(2):1061-1066.

Ravichandran, S., and N. Srinivasan, 2017. Effect of sowing density on the growth, yield and nutrient uptake of hybrid sunflower (Helianthus annuus L.) in rabi season. Int. J. Curr. Microbiol. App. Sci., 6(7):4193-4200.

Saleem, M., A. Arshadullah, A.W. Gandahi, S.M. Bhatti, and S. Velo, 2016. Effectiveness of colemanite ore as boron source for sunflower (Helianthus annuus L.) oil content and yield. Sindh Univ. Res. J., 48(4):931-934.

Schneiter, A.A., 1978. Non-destructive leaf area estimation in sunflower. Agron. J. 70:141-142.

Shehzad, M.A., M, Maqsood, T. Abbas, and N. Ahmad, 2016. Foliar boron spray for improved yield, oil quality and water use efficiency in water stressed sunflower. Sains Malaysiana, 45(10):1497-1507.

Snedecor, G.W., and W.G. Cochran, 1980. Statistical methods. seventh edition. Ames Iowa: The Iowa State University Press.

Süzer, S., 2010. Effects of nitrogen and plant density on dwarf sunflower hybrids. HELIA, 33(53):207-214. 
Tahir, M., M. YounasIshaq, A.A. Sheikh, M. Naeem, and A. Rehman, 2014. Effect of boron on yield and quality of sunflower under agro-ecological conditions of Faisalabad (Pakistan). Sci. Agri., 7(1):19-24.

Wimmer, M.A., and T. Eichert, 2013. Review: mechanisms for boron deficiency-mediated changes in plant water relations. Plant Sci., 203-204: 25-32. 